\title{
UJI MPN COLIFORM DAN IDENTIFIKASI FUNGI PATOGEN PADA AIR KOLAM RENANG DI KOTA MALANG
}

\author{
Edi Suriaman'), Wulandika Putri Apriliasari' ${ }^{2}$ \\ ${ }^{1)}$ Dosen Prodi D III Analis Kesehatan, Akademi Analis Kesehatan Malang \\ ${ }^{2)}$ Mahasiswa Prodi D III Analis Kesehatan, Akademi Analis Kesehatan Malang \\ Email : suriamans@gmail.com
}

\begin{abstract}
This study aimed to examine the content of fecal Coliform, and types of fungi pathogens contained in the water swimming pools in Malang. This study represents a descriptive type of research. The water samples were collected from two swimming pools located around the city of Malang. This study is divided into two: the testing of Coliform bacteria by MPN, and the identification of fungi. Results of Coliform MPN index was compared apply the MPN table. The results of all samples exhibit positive for Coliform, the number of Coliform bacteria contained in each of the two swimming pools respectively $75 \mathrm{cfu} / 100 \mathrm{ml}$ sample, and $43 \mathrm{cfu} / 100 \mathrm{ml}$ sample. Based on the identification of the fungus has been conducted, we have detected Penicillium sp., Fusarium sp., Aspergillus sp., Microsporum ferrugineum, and Microsporum audouinii. The spread of contamination bacterial and fungal pathogens in the water pose a threat to human health.
\end{abstract}

Keywords: MPN, Coliform, Fungi, Swimming Pool Water

\section{PENDAHULUAN}

Negara berkembang dapat diserang beragam jenis penyakit, bisa merupakan bawaan dari makanan maupun air. Beberapa contoh nya adalah Penyakit gastroenteritis Eschericia coli, salmonelosis, shigelosis, demam tifoid, paratifoid, amoebiasis maupun akibat mikosis. Melalui sistem pelaporan yang buruk atau tidak ada sama sekali pada kebanyakan negara berkembang, data statistik yang bisa diandalkan tentang penyakit ini tidak tersedia sehingga besaran insidensinya tidak dapat diperkirakan (WHO, 2005).

Secara umum air merupakan sumber kehidupan manusia, demikian halnya dengan air kolam renang. Sehingga air di dalam kolam renang yang digunakan untuk olah raga renang dan kualitasnya memenuhi syarat kesehatan sesuai dengan Peraturan Menteri Kesehatan (Depkes, 1990). Telah diketahui, air merupakan tempat bagi kolonisasinya berbagai jenis mikroba seperti bakteri, fungsi maupun yeast (Hussain et al., 2011). 
Penyakit yang penularannya terjadi melalui air yang terkontaminasi bakteri atau fungi patogen dan ditularkan kepada manusia melalui mulut atau sistem pencernaan disebut Waterborne disease. Penyakit paling umum yang disebabkan oleh Waterborne disease adalah diare yang disebabkan oleh adanya pencemaran bakteri jenis Coliform pada air. Diare menyebababkan kematian nomor dua pada anak dibawah usia lima tahun atau sekitar 15\% tahun 2008 (Kusuma et al, 2015; Winata dan Hartantyo, 2013).

Pengujian air secara mikrobiologi sangat diperlukan untuk mengukur kualitas proses sanitasi dan derajat kontaminasi cemaran mikroba dalam air terutama untuk air yang digunakan sehari-hari. Deteksi dan kuantifikasi tidak dilakukan dengan mengukur langsung jumlah cemaran mikroba patogen (penyebab penyakit) tetapi menggunakan mikroba indikator yaitu bakteri golongan seperti E. coli. Selain bakteri ternyata mikroba yang mencemari air adalah adanya kontaminasi fungi yang selama ini sangat jarang diidentifikasi, padahal resiko yang ditimbulkan juga sangat besar, karena keberadaan fungsi sulit untuk dikendalikan (Wahjuningsih, 2001; Yamaguchi et al, 2007).

Sedangkan keberadaan fungi pada air dapat mengakibatkan perubahan rasa maupun warna. Banyak spesies genus fungi seperti Aspergillus yang ditemukan pada air beperan sebagai agen penyebab penyakit seperti penyakit ginjal, liver, alergi, luka, dan meningkatkan resiko infeksi invasif. Investigasi pada Penicillium spp. yang seringkali ditemukan pada air berimplikasi pada munculnya penyakit alergi, asma, atau penyakit pernapasan lainnya (Hussain et al., 2011).
Pada penelitian ini, dilakukan deteksi pencemaran air kolam renang oleh fungi dan bakteri. Untuk mengetahui pencemaran air oleh bakteri patogen Coliform maka dilakukan pemeriksaan kandungan Coliform menggunakan metode Most Probable Number (MPN) berdasarkan standar yang ditetapkan oleh kementerian kesehatan RI. Sedangkan pemeriksaan fungi dilakukan dengan isolasi dan identifikasi jenis fungi yang mecemari air kolam renang.

\section{METODE}

Penelitian ini merupakan penelitian eksplorasi.

\section{Waktu dan Tempat Penelitian}

Sampel air kolam renang yang dilakukan adalah 2 tempat di kota Malang. Sampel diambil pada sore hari setelah digunakan oleh para pengunjung.

\section{Alat dan Bahan Penelitian}

Cawan petri steril, Erlenmeyer, tabung reaksi, rak tabung, mikro pipet, tip, botol sampel, oven, autoclave, lampu spiritus, kaca obyek, kaca penutup, ose mata, mikroskop, kapas, beaker glass $100 \mathrm{ml}$, incubator, plastic wrap, aluminium foil, media SDA, larutan fisiologis 0,9\%, akohol 70\%, Lactose Broth (LB), Brillian Green Lactose Broth (BGLB), air kolam renang.

\section{Prosedur \\ Pengambilan Sampel}

Alat pengambilan sampel sesuai jenis air yang akan diuji; alat dibilas dengan sampel yang akan diambil sebanyak tiga kali; sampel kemudian diambil sesuai 
peruntukan analisis. Dimasukkan kedalam wadah yang sesuai peruntukan analisis.

\section{Pemeriksaan Coliform}

Pemeriksaan Coliform dengan menggunakan metode Most Probable Number (MPN) yang terdiri dari presumptive test dengan menggunakan media Lactose Broth (LB) dengan metode 3 tabung, confirmative test dengan menggunakan media Brillian Green Lactose Broth (BGLB).

Apabila presumptive tes positif, maka dilakukan uji berikutnya yaitu MPN confirm tes. Namun apabila presumptive tes negatif, pengujian sampel selesai (Selian et al., 2014). Pada uji confirm tes yang menunjukkan hasil positif, diambil 1-2 ose sampel lalu dimasukkan dalam tabung yang berisi BGLB dan diinkubasi pada suhu $37^{\circ} \mathrm{C}$. Pembacaan dilakukan setelah 24-48 jam.

\section{Isolasi dan Identifikasi Fungi}

Sebanyak 0,1 ml sampel dari masingmasing botol dipipet pada cawan steril. Kemudian media PDA (Potato Dextrose Agar)) sebanyak $15 \mathrm{ml}$ dituangkan yang ke dalam cawan. Agar sampel dan media tercampur secara homogen, maka diputar secara perlahan. Hasil pencampuran diinkubasi pada temperatur ruang selama 57 hari. Fungi yang tumbuh kemudian diisolasi pada media PDA. Fungi yang sudah murni kemudian diidentifikasi secara makroskopis dan mikroskopis, dan diamati dengan menggunakan teknik Slide culture.

\section{Analisa}

Apabila semua pengujian MPN Coliform sudah menunjukkan hasil, maka dilakukan proses pengumpulan hasil, dan untuk melakukan interpretasi hitung angka MPN dengan rumus penghitungan MPN. Hasil pengamatan mikroskopis dan makroskopis fungi kemudian di sesuaikan dengan data yang terdapat pada Weber (2007), dan Ellis et al, (2007).

\section{HASIL DAN PEMBAHASAN}

\section{Hasil}

\section{Pemeriksaan MPN Coliform}

Berdasarkan hasil analisa tes presumtif (tabel 1), pada sampel kolam renang A diperoleh 8 tabung postif. Sedangkan pada kolam renang B diperoleh 7 tabung positif. Sehingga pada kolam renang $\mathrm{A}$ dan $\mathrm{B}$, pada tabung yang positif kemudian dilakukan confirm tes.

Tabel 1. Hasil presumtif tes

\begin{tabular}{crccc}
\hline \multirow{2}{*}{ No. Sampel } & \multicolumn{3}{c}{ Tes Presumtif } & \multirow{2}{*}{ Ket. } \\
\cline { 2 - 4 } & $\mathbf{1 0 ~} \mathbf{~ m m}$ & $\mathbf{1 ~ \mathbf { ~ m }}$ & $\mathbf{0 . 1} \mathbf{~ m m}$ & \\
\hline Kolam renang A & +++ & +++ & ++- & Lanjut \\
\hline Kolam renang B & +++ & ++- & +-- & Lanjut \\
\hline
\end{tabular}

Hasil confirm test menunjukkan adanya produksi gas pada tabung reaksi pada kedua kolam renang. Sehingga hasil positif pada confirm test dapat dimasukkan pada tabel jumlah perkiraan terdekat untuk mendapatkan nilai total bakteri Coliform yang terkandung pada $100 \mathrm{ml}$ sampel air seperti yang terlihat pada Tabel 2. Berdasarkan hasil confirm test diperoleh indeks MPN pada kolam renang 
Tabel 2. Hasil confirm test untuk Coliform

\begin{tabular}{ccccc}
\hline No. Sampel & \multicolumn{3}{c}{ Confirm tes } & Indeks MPN \\
\cline { 2 - 4 } & $\mathbf{1 0 ~} \mathbf{~ m m}$ & $\mathbf{1 ~} \mathbf{~ m l}$ & $\mathbf{0 . 1} \mathbf{~ m m}$ & $(\mathbf{c f u} / \mathbf{1 0 0} \mathbf{~ m l})$ \\
\hline Kolam renang A & +++ & +-- & -+- & 75 \\
\hline Kolam renang B & +++ & +-- & --- & 43 \\
\hline
\end{tabular}

\section{Identifikasi Fungi}

Setelah dilakukan identifikasi jenis terhadap isolat kapang yang ditemukan, maka diperoleh sebanyak 5 jenis kapang yaitu Penicillium sp., Fusarium sp., Aspergillus $\quad$ sp., $\quad$ Microsporum ferrugineum, dan Microsporum audouinii.

Ciri makroskopis fungi Penicillium sp. yang ditemukan adalah berwarna putih-hijau, bentuk koloni rugosa, tekstur koloni velvety. Sedangkan ciri mikroskopisnya adalah konidia banyak, tersusun seperti rantai pada ujung fialid, dan mempunyai dinding yang tipis. Pada fungi Fusarium sp. ciri makroskpis adalah warna putih pudar, bentuk koloni flat, tekstur koloni cottony, diameter per 4 hari adalah $5 \mathrm{~cm}$. Sedangkan ciri mikroskopisnya adalah konidiofor pendek, tunggal, miselium aerial, macroconidia fusiform, sedikit melengkung, sebagian besar tiga septate. Microconidia banyak, tidak pernah dalam rantai, sebagian besar non-septate. Bentuk : ellips atau silinder, lurus atau sering melengkung, 5-12 x2.3 - 3,5 $\mu \mathrm{m}$. Chlamydospores : terminal atau kabisat. Ciri makroskpis Aspergillus sp. yang ditemukan adalah berwarna putih-hijau, bentuk koloni flat, tekstur koloni cottony, konidiofor bercabang dipangkalnya, permukan dinding konidiofor kasar dan berdinding tipis. Konidianya berlimpah pada konidiofor.

Fungi Microsporum ferrugineum memiliki ciri makroskopis berwarna kuning, bentuk koloni bersifat verrucose, tekstur koloni berbentuk velvety, pertumbuhan koloni lambat. Pigmentasi permukaan dapat bervariasi dari krem ke kuning ke merah tua dan bentuk putih datar kadang-kadang terjadi. Sedangkan ciri mikrsokopisnya adalah microconidia atau macroconidia tidak diproduksi. Percabangan hifa tidak teratur dengan dinding yang khas ("hifa bambu") dan chlamydospores terlihat. Hifa berbentuk seperti bambu merupakan karakteristik khas dari spesies ini.

Pada fungi Microsporum audouinii, adapun ciri makroskopisnya adalah berwarna putih pudar (sedikit keabuabuan), koloni berbentuk flat, tekstur koloni cottony, koloni datar, menyebar, putih keabu-abuan. Permukaan berbulu halus dan padat. Ciri mikroskopisnya adalah Macroconidia dan microconidia jarang diproduksi. Chlamydospores berdinding tebal. Ketika terdapat macroconidia dapat mirip dengan $M$. Canis tapi biasanya dalam bentuk yang lebih halus dan lebih teratur. Juga terdapat pectinate hifa dan raket hifa (terdapat segmen hifa yang bengkak di salah satu bagian). 


\section{Pembahasan}

\section{Pengujian Coli Dengan Metode MPN}

Kedua sampel dari kolam renang berdasakan pengujian Coliform dengan MPN menunjukkan hasil yang positif dikarenakan bakteri tersebut mampu memfermentasikan laktosa oleh enzim bakteri dari kelompok coli yang menghasilkan asam dan gas. Sedangkan melalui penggunaan media BGLB pada uji confirm tes, maka bakteri non coli dapat dihambat pertumbuhannya oleh bile dan brilliant-green yang terdapat dalam media (Wahjuningsih, 2001).

Hasil penelitian ini memperlihatkan bahwa kedua jenis air kolam renang di Kota Malang mangandung bakteri kelompok Coliform. Menurut Widiyanti dan Ristiati (2004), Coliform merupakan grup bakteri yang digunakan sebagai indikator adanya polusi kotoran dan kondisi yang tidak baik terhadap air, maupun bahan makanan. Kelompok bakteri Coliform dicirikan sebagai bakteri berbentuk batang, gram negatif, tidak membentuk spora, aerobik dan anaerobik fakultatif yang memfermentasi laktosa dengan menghasilkan asam dan gas dalam waktu 24 jam pada suhu $35^{\circ}$ C. Tentunya dengan keberadaan bakteri Coliform di dalam makanan/minuman menunjukkan kemungkinan adanya mikroba yang bersifat enteropatogenik dan atau toksigenik yang berbahaya bagi kesehatan.

Menurut klasifikasi dari WHO, standar kadar Coliform untuk air yang baik atau disebut conformity adalah 0 $\mathrm{cfu} / 100 \mathrm{ml}$ sampel. Sedangkan nilai
Coliform 1-10 cfu/100 ml sampel dinyatakan sebagai air yang berada pada kondisi low risk. Sedangkan air dengan kondisi intermediate risk merupakan air yang mengandung Coliform 10-100 $\mathrm{cfu} / 100 \mathrm{ml}$ sampel. Air dengan total nilai Coliform 100-1000 cfu/100 ml sampel merupakan high risk water (Sarah et al, 2014). Sedangkan menurut Peraturan Menteri Kesehatan RI No. 416/Menkes/ Per/IX/1990, nilai maksimum MPN Coliform untuk air kolam renang adalah $>200$ (Depkes, 1990). Sehingga sampel air kolam renang yang di uji masih layak untuk digunakan, meskipun menurut standar WHO sudah masuk pada skala intermediate risk.

Bakteri golongan Coliform pada umumnya ada pada kotoran manusia dan hewan yang dapat ditemukan dalam jumlah yang banyak. Bakteri Coliform (Total Coliform) juga tersebar secara luas di alam terbuka. Bakteri golongan Coliform adalah mengacu pada bakteri golongan Enterobacteriaceae. Beberapa dari bakteri tinja yang bersifat patogen juga termasuk dalam golongan ini. Genus bakteri yang termasuk dalam Coliform adalah Escherichia, Klebsiella, Enterobacter, Citrobacter, Yersinia, Serratia, Hafnia, Pantoea, Kluyvera, Cedecea, Ewingella, Moellerella, Leclercia, Rahnella, Yokenella. Bakteri Coliform seperti spesies Citrobacter, Enterobacter dan Klebsiella juga dapat ditemukan pada lingkungan seperti tanah, vegetasi atau permukaan air, yang keberadaannya tidak selalu berkaitan dengan kontaminasi fekal. Manusia yang terpapar oleh air yang terkontaminasi 
Coliform mengakibatkan gejala demam, diare dan kram abdominal, nyeri dada, atau menyebabkan penyakit hepatitis. Selain E. coli, patogen fekal lain yang menjadi ancaman bagi kesehatan adalah Salmonella, Shigella, dan Psuedomonas aeruginosa (Sengupta dan Saha, 2013).

Selain terkandung bakteri Coliform, kedua sampel air kolam renang tersebut juga tercemar oleh fungi, yaitu Penicillium sp., Fusarium sp., Aspergillus $\quad$ sp., $\quad$ Microsporum ferrugineum, dan Microsporum audouinii. Parveen et al (2011), melaporkan bahwa beberapa jenis fungi seperti Aspergillus, Penicillium dan Fusarium, Aspergillus niger, A. fumigatus, A. flavus, A. versicolor, dan Cladosporium sphaerospermum, seringkali ditemukan dalam air pada sungai.

Goncalves et al (2006), dalam penelitiannya menemukan bahwa Penicillium merupakan fungi yang berlimpah pada keran air. Hal ini disebabkan konidia yang dihasilkan oleh jenis fungi ini mampu beradaptasi dengan baik dan penyebarannya melalui udara. Sedangkan hasil penelitian Parveen et al (2011), menyatakan bahwa Aspergillus merupakan fungi yang umum ditemukan dalam air. Jenis spesies yang ditemukan adalah $A$. niger dengan frekuensi (83.33\%), sedangkan A. flavus dan A. fumigatus dengan frekuensi $58.33 \%$. Hasil penelitian Krishnaveni et al (2016), menemukan berbagai jenis Microsporum spp. yang berada dalam berbagai jenis air di selatan Tamil Nadu. Spesies yang ditemukan adalah
Microsporum canis, M. gypseum, $M$. nanum, $M$. persicolor $\operatorname{dan} M$. audouinii. Fungi Microsporum spp, merupakan patogen yang memiliki kemampuan untuk melakukan penetrasi alami pada keratin dan memainkan peranan sebagai agen keratinolisis.

Keberadaan fungi dalam kedua kolam renang yang di uji, memperlihatkan adanya kontaminasi air akibat dipengaruhi oleh beberapa hal, misalnya sumber air, temperatur air, pola perawatan dan pemeliharaan air. Hal ini tentu menjadikan sumber ancaman bagi kesehatan orang-orang yang akan memanfaatkannya. Sebagai tambahan, fungi dalam air bisa juga berkurang keberadaannya dengan pemberian disinfektan seperti klorin. Akan tetapi pemberian klorin harus memperhatikan ketentuan yang berlaku. Fungi dalam air selain menyebabkan infeksi pada kulit, fungi juga dapat menghasilkan mikotoksin. Hal studi memperlihatkan bahwa aflatoksin dan senyawa lainnya dapat dideteksi pada tangki air. Fungi dengan biomassa sekitar $103 \mathrm{cfu} / \mathrm{l}$ dapat menyebabkan bau pada air (Goncalves et al, 2006).

Berdasarkan hasil penelitian ini, sumber pencemaran dapat berasal dari aktivitas pengunjung dalam kolam atau dari bahan baku air untuk kolam renang. Untuk mengontrol aktivitas pengunjung sangat sulit dilakukan, hanya bisa diberikan himbauan agar tidak kencing dalam kolam renang. Oleh karena itu perlu juga dikaji apakah bahan baku yang berasal dari daerah tersebut layak digunakan. Seharusnya bahan baku 
utama yang digunakan adalah air yang diambil dari sumber yang terjamin kualitasnya, yaitu terlindungi dari cemaran kimia dan mikrobiologi yang bersifat merusak/mengganggu kesehatan, serta diperiksa secara berkala terhadap organoleptik (bau, rasa, warna), fisika, kimia, dan mikrobiologi (Wandrivel et al, 2012).

\section{KESIMPULAN}

Resiko infeksi akibat penggunaan air kolam renang meningkat jika tidak memperhatikan standar kualitar air. Hasil penelitian ini menunjukkan bahwa air pada kedua kolam renang positif telah terkontaminasi oleh bakteri Coliform. Berdasarkan standar Peraturan Menteri Kesehatan air pada kolam renang masih layak digunakan, meski masuk dalam skala intermediate risk. Selain itu air kolam renang ini juga terkontaminasi oleh fungi yang semakin menambah rendahnya kualitas air.

\section{UCAPAN TERIMAKASIH}

Penulis mengucapkan terimakasih kepada Direktur Akademi Analis Kesehatan Malang, Dr. Heri Sudarsono yang telah mendukung dan membiayai penelitian ini. Terimaksih juga untuk tim laboratorium di Akademi Analis Kesehatan Malang yang telah banyak membantu atas kelancaran selama proses penelitian berlangsung.

\section{PUSTAKA}

Depkes RI. 1990. Peraturan Kementerian Kesehatan. Nomor : 416 tahun 1990. Tentang Syarat-syarat dan Pengawasan Kualitas Air. Departemen Kesehatan RI.

Ellis D., Davis S., Alexiou H., Handke R., and Bartley R. 2007. Description of Medical Fungi 2nd Edition. School of Molecular \& Biomedical Science University of Adelaide. Australia.

Goncalves, A.B., Russell, R., Paterson M., and Lima, N. 2006. Survey and Significance of Filamentous Fungi from Tap Water. Int. J. Hyg. Environ.-Health. 209 : 257-264

Hussain, T., Ishtiaq, M., Hussain, A., and Sultana, K. 2011. Study of Drinking Water Fungi and its Pathogenic Effects on Human beings From District Bhimber, Azad Kashmir, Pakistan. Pak. J. Bot. 43(5): 2581-2585.

Krishnaveni, G., Rekha, C. B., Rajendran, P., Nithyakalyani, V., and Vithiyavani, P. 2016. Antidermatophytic Potential of Selected Medicinal Plants against Microsporum Species. Int. J. Curr. Res. Biosci. Plant Biol. 3(5): 102106.

Kusuma, E. A., Rasyid, R., dan Endrinaldi. 2015. Identifikasi Bakteri Coliform pada Air Kobokan di Rumah Makan Kelurahan Andalas Kecamatan Padang Timur. Jurnal Kesehatan Andalas. 4(3) : 845-849 
Parveen, S., Lanjewar, S., Sharma, K., and Kutti, U. 2011. Isolation of Fungi from the Surface Water of River. Journal of Experimental Sciences. 2(10): 58-59.

Sarah, R. E., Apriliana, E., Soleha T. U, and Warganegara, E. 2014. Most Probable Number (MPN) Test of Coliform Bacteria in Household

Selian, L. S., Warganegara, E., and Apriliana, E. 2014. Most Probable Number (MPN) Test and Coliform Bacteria Detection in Instant Drinks in Elementary School at Sukabumi District in Bandar Lampung. http://jukeunila.com/wpcontent/uplo oads/2016/05/14Lailatus-Syfa-S.pdf. Akses 12 November 2016

Sengupta, C., and Saha, R. 2013. Review Article : Understanding Coliforms a Short Review. International Journal of Advanced Research. Volume 1, Issue 4 : 16-25.

Wahjuningsih, E. 2001. Substrat Khromogenik-Fluorogenik pada Uji Cemaran Coli Dalam Air. Unitas. Vol. 9, No. 2: 44-56

Wandrivel, R., Suharti, N., dan Lestari, Y. 2012. Kualitas Air Minum Yang Diproduksi Depot Air Minum Isi Ulang Di Kecamatan Bungus Padang Berdasarkan Persyaratan Mikrobiologi. Jurnal Kesehatan Andalas. 1(3) : 129-133.

Webster, J., and Weber, R. 2007. Introduction To Fungi $3^{\text {rd }}$ Edition. Cambridge University Press. New York.
WHO. 2005. Penyakit Bawaan Makanan: Fokus Pendidikan Kesehatan. Alih bahasa: dr. Andry Hartono, Sp.GK. EGC : Jakarta.

Widiyanti, N. L. P. M., dan Ristiati, N. P. 2004. Analisis Kualitatif Bakteri Coliform pada Depo Air Minum Isi Ulang di Kota Singaraja Bali. Jurnal Ekologi Kesehatan. 3 (1) : 64 -73.

Winata, E., dan Hartantyo, E. 2013. Kualitas Air Tanah di Sepanjang Kali Gajah Wong Ditinjau dari Pola Sebaran Escherichia Coli (Studi Kasus Kecamatan Umbulharjo). Jurnal Fisika Indonesia. No: 50, Vol XVII : 8-12.

Yamaguchi, M. U., Rampazzo, R. C. P., Ogatta, S. F. Y., Nakamura, C. V., Nakamura, T. U., Filho, B. P. D. 2007. Yeasts and Filamentous Fungi in Bottled Mineral Water and Tap Water from Municipal Supplies. Brazilian Archives of Biology and Technology An International Journal. 50 (1) : 1-9. 